\title{
Scientific-Methodical Foundations of Estimation of Territorial Communities' Endogenous Capacity in Ukraine in Conditions of Decentralization
}

\author{
Iryna Hrynchyshyn \\ Regional Financial Policy Department \\ M. I. Dolishniy Institute of Regional \\ Research of NAS of Ukraine \\ Lviv, Ukraine \\ i.hrynchyshyn@ukr.net \\ Nazariy Popadynets \\ Regional Economic Policy Department \\ M. I. Dolishniy Institute of Regional \\ Research of NAS of Ukraine \\ Lviv, Ukraine \\ popadynets.n@gmail.com
}

\author{
Olena Panukhnyk \\ Economics and Finance Department \\ Ternopil Ivan Puluj National Technical \\ University \\ Ternopil, Ukraine \\ panukhnyk@gmail.com \\ Khrystyna Patytska \\ Regional Financial Policy Department \\ M. I. Dolishniy Institute of Regional \\ Research of NAS of Ukraine \\ Lviv, Ukraine \\ pelechata@meta.ua
}

\author{
Mariana Bil \\ Social and Humanitarian Development \\ Of The Region Department \\ M. I. Dolishniy Institute of Regional \\ Research of NAS of Ukraine \\ Lviv, Ukraine \\ bmm1983@gmail.com \\ Iryna Leshchuh \\ Spatial Development Department \\ M. I. Dolishniy Institute of Regional \\ Research of NAS of Ukraine \\ Lviv, Ukraine \\ ira_leschukh@ukr.net
}

\begin{abstract}
Revealing the problems of inefficient use of territorial communities' endogenous capacity and outlining the opportunities of its increase as an important factor of forming of capable territorial communities in Ukraine are the relevant scientific tasks in current conditions of reforming of local selfgovernance and authorities' territorial organization. Unequal development of territorial communities brings to the fore the need to comprehensively analyze their endogenous capacity: natural resources wealth of the territory, social infrastructure and residents' quality of life as well as financial and investment opportunities of territorial communities. Endogenous capacity of a community was complexly evaluated based on the developed methodics of evaluation of territorial community's endogenous capacity (across natural resources, financial, investment and human components). The methodics was tested for the first time on the example of nine consolidated territorial communities: Novokalynivska, Lytovezka, Povorska, Holobska, Ustyluzka, Tsarychynska, Pokrovska, Vasylkivska and Vysotska, which were selected by the parameters of own income per capita and subsidiarity level. Testing of the methodics resulted in the development of suggestions for the created communities in Ukraine in terms of improvement of the efficiency of forming, use and revealing the reserves to increase endogenous capacity as well as suggestions for authorities regarding the ways to strengthen the communities' capacity and reduce their subsidiarity level.
\end{abstract}

Keywords - territorial community's capability, endogenous capacity, natural resources capacity, human capacity, financial capacity, investment capacity, budget decentralization

\section{INTRODUCTION}

Decentralization reform is one of the most successful in Ukraine. Its active phase began in 2014. The further progress of the reform depends not only on the political will of central public authorities, but also on the communities' activity. The process is irreversible to some extent as far as many communities have felt their capacities to solve local problems and have gained access to real resources. Therefore, the next stage of the development of Ukrainian society and economy should be based on local initiative. The further reform of administrative-territorial structure and change of an algorithm of resources flows between central, regional and local institutes depend on it.

Revealing the problem of inefficient use of territorial communities' endogenous capacity and outlining the opportunities of its increase in the context of maintaining of their capabilities are the relevant scientific tasks in current conditions of implementation of authorities' decentralization reform. Such scientific research requires forming of theoretical-methodical foundations of estimation of territorial communities' endogenous capacity taking into account natural resources, financial, investment and human peculiarities of their development. The results of calculations provide an opportunity to reveal the reserves to increase communities' endogenous capacity. From the managerial viewpoint, it is important to examine the examples of successful communities, which prove the need for further creation of territorial communities in Ukraine in order to expand their competences in the sphere of local governance. Therefore, the abovementioned brings to the fore the need for scientific research in terms of comprehensive examining of the components of territorial communities' endogenous capacity.

Endogenous capacity of a territorial community is defined by its internal resources, which influence the conditions and quality of the capacity. Endogenous capacity is not only the complex of resources of some territory, but also the ability to reveal them and to attract unutilized development sources in order to secure efficient functioning of some territory [1, p. 43]. Community's functioning depends on the efficiency of the use of its endogenous capacity. A community is capable if it can provide the proper level of public services under the available conditions in the process of its functioning and use its capacity for the development of the community. 
Opportunity to estimate endogenous capacity constitutes the practical importance of its research. For that purpose, it is relevant to use structural approach emphasizing the following capacity components - natural resources, human, financial and investment. Each of them has its own functioning load.

Thus, I. Shkuratova defines natural resources capacity as an ability of natural systems to provide the quality and quantity of natural resources necessary for economic development under the formed economic conditions while keeping their natural condition [2]. According to P. Zhuk, natural resources capacity can be considered as an ability of natural resources to meet the needs of the process of production of material, cultural and spiritual benefits in the form of goods and services to secure human living activity and improvement of human welfare [3]. O. Suhina et al. ground their research on more detailed research of natural resources capacity, namely in terms of environmental damage [4]. In our opinion, the composition of natural resources capacity of territorial communities should be examined across the types of natural resources, dividing the territories they are located at according to legal status (lands of public or civil (municipal) ownership), functional needs, volumes of proven reserves of mineral deposits, licenses for use, etc. Environmentally dangerous territories or those subject to negative impact in the future should be defined separately.

Human component is a very important estimation component of endogenous capacity. Human capacity content has a broad functional meaning. According to R. Yakovenko, in the broad outlook it characterizes the new stage of human development, when intellectual, social, psychological and cultural values play an increasing role in addition to productive opportunities [5, p. 188]. According to S. Skyba, human capacity encompasses modern scientific views over the abilities of a person and a state from the viewpoint of their approaching the harmonious development [6, p. 15]. In more practical sense, as considered by O. Stefanyshyn and V. Pyts, human capacity characterizes the aggregate opportunities, available and accumulated reserve of genetically designed human talents, skills, health, abilities, motivations as well as the gained knowledge and skills and ability to work [7, p. 163]. In our point of view, human capacity of a territorial community represents a set of physiological, socio-psychological, intellectual-labour, socio-stratification and ethnocultural abilities of a society that can be used now or in the nearest future and implemented in an environment that secures their development (reproduction, accumulation, qualitative exploitation).

It is reasonable to consider financial capacity of a territorial community in the context of interdependency of financial resources accumulated on the territory of a community and reserves of their increase as well as directions and opportunities of exploitation in order to secure socio-economic development of the territory. S. Sember et al. consider financial capacity to be an important determinant of community's capacity as far as capacity itself is not the phenomenon related to opportunities and capacity of a community to direct financial resources (including the "shadow" ones) to meeting the needs [8]. N. Trusova outlines three approaches to the definition of financial capacity: resources-based, complex and approach based on the capability viewpoint [9]. T. Nazarova divides definition in four groups and names resources-based and complex approaches as well as functional approach and the one based on efficiency of financial results [10]. H. Voznyak et al. research the financial capacity of consolidated territorial communities (CTCs) by evaluating the first stage of financial decentralization in Ukraine and finding the major mechanisms of budget redistribution at various levels [11]. We deem budget capacity to be the foundation of financial capacity of an administrative-territorial unit. Its key element is the tax component formed as the result of the use of real, perspective and extended tax basis. The tax paying ability of a territorial community is formed based on tax capacity, which is the key factor of securing the development of the territorial community's financial capacity.

Endogenous investment capacity takes an important place in socio-economic development of a territorial community. M. Pityulych et al. characterize it as a set of objective preconditions (opportunities) to conduct investment activity at a certain territory [12]. M. Kukosh defines that investment capacity is a dynamic category: its forming, conditions and level of use are determined to a large extent by both endogenous factors of influence (stipulated by the development and the efficiency level of the use of other partial capacities, which is why investment capacity should be considered in close connection with them) and exogenous factors stipulated by the conditions and characteristics of macroenvironment the community functions in [13]. Having analyzed these research, we deem that endogenous investment capacity of a territorial community is a set of objective preconditions (natural, economic and social) and internal available resources (financial, labour and productive) necessary to conduct investment activity with the view to achieve sustainable development of a territorial community.

We hypothesize that capability and functioning efficiency of a territorial community can be determined based on estimation of its endogenous capacity, which is formed by natural resources, human, financial and investment components. To validate the generated hypothesis we have developed and tested the methodics of estimation of the abovementioned components of a territorial community's endogenous capacity.

\section{THE AIM AND METHOD USED}

The paper aims to expand the theoretical and methodical foundations of the research of territorial communities' endogenous capacity in Ukraine in the context of explaining the opportunities of its increase and securing these communities' capabilities.

The goals of the paper are the following: to define theoretical nature of endogenous capacity and its components; to describe the methodics of estimation of territorial communities' endogenous capacity and its adaptation on the example of nine consolidated territorial communities in Ukraine.

The authors' methodics of estimation of a territorial community's endogenous capacity was used to achieve the results of the research. It stipulates calculation of sub-indices for each component of the capacity with determining of stimulants and deterrents and standardization of parameters. 
The system of parameters in Table 1 was chosen for calculations. As far as statistics on territorial communities is still being formed in Ukraine, the requests were sent to the communities and oblast state administrations in order to receive necessary data for calculations. The methodics was tested on 9 consolidated territorial communities in Ukraine, which were selected by the parameters of their own income per capita and subsidiarity level.

TABLE I. PARAMETERS OF ESTIMATION OF A TERRITORIAL COMMUNITY'S ENDOGENOUS CAPACITY

\begin{tabular}{l|l|} 
Component & \multicolumn{1}{c}{ Major parameters } \\
$\begin{array}{l}\text { Natural } \\
\text { resources } \\
\text { capacity }\end{array}$ & $\begin{array}{l}\text { Parameters of land availability and structure; parameters } \\
\text { of mineral resources availability; parameters of tax } \\
\text { payments related to land use; rent payments for the use of } \\
\text { natural resources (26 parameters in total) }\end{array}$ \\
$\begin{array}{l}\text { Human } \\
\text { capacity }\end{array}$ & $\begin{array}{l}\text { Demographic parameters; intellectual-labour parameters; } \\
\text { socio-management parameters; socio-economic } \\
\text { parameters; socio-infrastructural parameters; cultural } \\
\text { parameters (44 parameters in total) }\end{array}$ \\
$\begin{array}{l}\text { Financial } \\
\text { capacity }\end{array}$ & $\begin{array}{l}\text { Income parameters (income tax, excise tax, land fee; real } \\
\text { estate tax; single tax); expenses parameters (expenses on } \\
\text { management, education, healthcare, social protection, }\end{array}$ \\
$\begin{array}{l}\text { Investment } \\
\text { capacity }\end{array}$ & $\begin{array}{l}\text { Parameters of provision with financial resources; } \\
\text { parameters of provision with labour resources; } \\
\text { parameters of provision with productive resources (13 } \\
\text { parameters in total) }\end{array}$ \\
\hline
\end{tabular}

Estimation of natural resources capacity is conducted based on calculation of the following components:

- land availability and structure - for agricultural use, ha; residential and public development, ha; forestry use, ha; for industry, transport, communication, energy, defense and other purposes, ha; water fund, ha; recreational use, ha; other use, ha;

- mineral resources availability - volumes: oil, million tons; gas, million $\mathrm{m} 3$; harvested wood, thous. m3; peat, million $\mathrm{m} 3$; construction sand, million $\mathrm{m} 3$; grey and white clay, million $\mathrm{m} 3$; rubble, million tons;

- tax payments related to land use - land fee rates established at the territory of a CTC, \%; number of land fee payers, persons; number of persons having privileges in payment of land tax, persons; corporate land tax, UAH; individual land tax, UAH;

- rent payments - rent payment for the special use of forest resources, UAH; rent payment for subsoil use, UAH; rent payment for subsoil use to extract oil, UAH; rent payment for subsoil use to extract natural gas, UAH; rent payment for subsoil use to produce gas condensate, UAH; rent payment for subsoil use to extract amber, UAH; rent payment for special use of water, UAH.

Estimation of human capacity in the structure of endogenous capacity of a community includes accounting of the parameters by the following components

- demographic - number of registered population, persons; difference between the registered and resident population, persons; demographic reproduction in the last 5 years (losses, growth), \%; number of households, units; share of retirement age persons (over 60 years), \%; share of youth up to 15 years, \%; natural population growth, persons; population density, persons/sq. km;
- intellectual-labour - number of economically active population, persons; number of employed, persons; number of self-employed, persons; number of unemployed, persons; number of persons abroad (migrants), persons; number of job places in economic entities operating in a community, units; average monthly wages of employed by economic entities operating in a community, UAH;

- socio-management - number of employed in the apparatus of community council, persons; change of the number of employed in the apparatus of community council from the moment of its creation, \%; average monthly wages of employed in the apparatus of community council, UAH; number of intermunicipal cooperation projects, units; number of cross-border and international cooperation projects, units; number of planned meetings of community managers with business representatives, times/year;

- socio-economic - disposable income per capita, UAH; share of persons that require social protection, \%; share of persons that receive subsidies, \%; number of economic entities operating in a community, units; number of individual entrepreneurs operating in a community, units; number of specific spatial entities for support of business (business incubators, industrial parks, etc), units;

- socio-infrastructural - number of pre-school education establishments, units; number of general education establishments, units; number of vocational training institutions, units; number of higher education establishments, units; number of healthcare facilities (family doctors' offices, paramedical and midwifery stations, ambulance stations, hospitals), units; number of trade facilities (excisable goods), units; available Center of Administrative Services at the territory of a community or the decision on its opening this year, units; available police department at the territory of a community or the decision on its opening this year, units; available fire brigade or the decision on its opening this year, units; share of households connected to natural gas supply, \%; share of households connected to centralized system of water supply, \%; length of paved roads, $\mathrm{km} / \mathrm{sq} \mathrm{km}$ of the area;

- cultural - number of cultural facilities (theatres, concert halls, museums), units; number of art schools (musical, artistic, chorographical, etc), units; number of sports facilities, units; number of exhibitions and fairs at the territory of CTC, units per year; number of youth centers that function at the territory of a community.

Financial capacity. Analysis of financial capacity of a territorial community stipulates complex quantitative and qualitative estimation of its socio-economic situation, substantiation of strengths and weaknesses of local governments' functioning, determining of the place and role of local budget in securing of the territories' socio-economic development.

Based on systematization of approaches and methods and determining of the aim and key tasks of the research, we suggest analyzing the financial capacity of a territorial community across two criteria: 1) efficiency of its forming (taking into account the major budget forming taxes); 2) efficiency of its use (suggested to be analyzed by estimation of the defined parameters by separate groups of functional classification of expenses). 
Efficiency of forming of a territorial community's financial capacity is suggested to be analyzed by estimation of parameters grounded on budget forming taxes (see Table 1)..

The following parameters are taken into account in calculation of financial capacity in terms of expenses:

- managerial expenses - share of expenses on management in the structure of expenses, \%; number of employed for local governments per 1000 population, persons; average monthly wages of employed in the apparatus of community council, UAH; number of prepared and submitted projects, units;

- expenses on education - share of expenses on education in the structure of expenses, \%; share of municipal services in the structure of expenses on education, \%; level of expenses on school education per capita, UAH; level of expenses on school education per 1 child, UAH; average number of pupils in the classes of general education school in a territorial community, persons; share of graduates from general education establishments, who received 160 points and more at external independent estimation in Ukrainian language in the total number of pupils tested in Ukrainian language, \%; level of expenses on pre-school education per 1 child, UAH; average number of children in a pre-school establishment, UAH; share of pre-school age children covered by pre-school education establishments in the overall number of pre-school children, \%; level of expenses on out-of-school education per 1 child, UAH; number of children covered by out-of-school education in the total number of school-age children, \%;

- expenses on healthcare - expenses on healthcare per capita, UAH; number of general practice doctors per 1000 persons of actual population at the end of the year, persons;

- expenses on social protection - number of persons covered by social programs and services funded from local budget per 1000 population; level of expenses on social protection per capita, UAH; level of expenses per 1 person requiring social protection, $\mathrm{UAH}$;

- expenses on culture and sports - level of expenses on culture per capita, UAH; level of expenses per 1 cultural facility, UAH; replenishment of library collection, units; number of sold tickets to events, units; level of expenses on sports per capita, UAH; holding sports and training camps and competitions in Olympic disciplines, units; share of expenses on economic activity in total expenses of local budget, \%; level of expenses on economic activity per capita, $\mathrm{UAH}$; growth rate of expenses per capita; level of expenses on implementation of investment projects per capita, UAH; level of expenses on energy saving per capita, UAH; level of expenses on promotion of entrepreneurship development per capita, UAH; level of expenses on maintenance and development of roads per capita, UAH.

Suggested methodics contributes to analyzing of the following aspects:

- in the first place, efficiency and reasonability of expenses on management in a community and comparison of the practice of management process organization in various communities;
- in the second place, emphasizing the peculiarities of the expenses of social nature and their efficiency;

- in the third place, determining the focus of expenses of communities' local budgets on economic activity and main directions of their undertaking.

The authors' methodics of estimation of territorial communitiese endogenous investment capacity is based on calculation of sub-indices of provision with financial, labour and productive resources:

- parameters of provision with financial resources: capital investment per capita, thous. UAH; own revenues of local budget per capita, thous. UAH; number of economic entities located at the territory of a community but paying the income tax to the budget by the registration place of main office per 1 thous. of actual population; average monthly wages of employed by economic entities operating in a community, $\mathrm{UAH}$; average monthly wages of employed in the apparatus of community council, UAH; number of persons abroad for permanent or temporary job (migrants) per 1 thous. of actual population;

- parameters of provision with labour resources: share of employed in the total number of working age population, \%; share of working age population in the structure of population, \%; share of employed in the total number of actual population, $\%$;

- parameters of provision with productive resources: number of industrial enterprises per 1 thous. of actual population, units; number of economic entities operating at the territory of a community per 1 thous. of actual population, units; number of individual entrepreneurs that operate in a community per 1 thous. of actual population, units; number of economic entities that undertake retail trade in excisable goods at the territory of a community per 1 thous. of actual population, units;

Suggested parameters form the methodics of analysis of endogenous capacity's components at the level of separate territorial communities.

\section{RESEARCH RESULTS}

In order to test the methodics of estimation of terrritorial communities' endogenous capacity the communities were divided by the parameters of own income per capita and subsidiarity level. The group for analysis included over 250 communities, however first testing was performed for 9 consolidated territorial communities in Ukraine (Table 2).

Natural resources capacity is estimated across such components as parameters of land availability and structure, parameters of payment of taxes related to land use and rent payments for the use of natural resources (Fig. 1). The parameters of availability of mineral resources were not considered in estimation for the communities under research, because the level of these resources' development is very low.

Analysis shows that Holobska, Ustyluzka and Vysotska CTCs use the available structure of their lands for the development of their communities more compared to the other ones. The use of land capacity requires the intensification of such processes in other communities as far as proper land use is one of the main ways to secure budget 
revenues in a community. Regarding the use of such component as payments of taxes related to land use, Pokrovska and Tsarychynska CTCs use it the least. They need stimulus on part of governing bodies, since these taxes are another way to fill community's budget. Rent payments are the smallest in Lytovezka, Tsarychynska and Vysotska CTCs, causing the need for detailed examining of an opportunity to develop and extract available mineral resources in a community.

TABLE II. BASIC PARAMETERS OF CONSOLIDATED TERRITORIAL COMMUNITIES IN UKRAINE COVERED BY ENDOGENOUS CAPACITY CALCULATIONS, 2018

\begin{tabular}{|c|c|c|c|c|c|c|}
\hline Community & 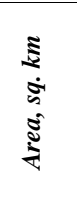 & 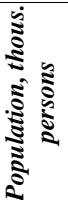 & 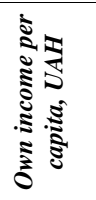 & 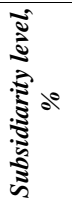 & 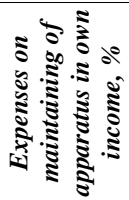 & 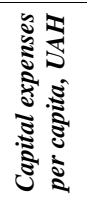 \\
\hline $\begin{array}{l}\text { Holobska } \\
\text { (Volyn region) }\end{array}$ & 298.8 & 8.7 & 2089.4 & 22.7 & 35.0 & 535.5 \\
\hline $\begin{array}{l}\text { Lytovezka } \\
\text { (Volyn region) }\end{array}$ & 122.4 & 4.2 & 2985.9 & -4.3 & 40.1 & 1071.1 \\
\hline $\begin{array}{l}\text { Novokalynivska } \\
\text { (Lviv region) }\end{array}$ & 108.3 & 7.3 & 3259.8 & -3.1 & 35.8 & 1201.1 \\
\hline $\begin{array}{l}\text { Povorska } \\
\text { (Volyn region) }\end{array}$ & 297.2 & 4.5 & 2000.6 & 21.1 & 30.4 & 1101.6 \\
\hline $\begin{array}{l}\text { Pokrovska } \\
\text { (Dnipro region) }\end{array}$ & 440.3 & 17.0 & 3623.9 & 4.1 & 18.4 & 1017.1 \\
\hline $\begin{array}{l}\text { Tsarychynska } \\
\text { (Dnipro region) }\end{array}$ & 453.5 & 15.0 & 3366.7 & 7.5 & 19.1 & 1437.8 \\
\hline $\begin{array}{l}\text { Ustyluzka } \\
\text { (Volyn region) }\end{array}$ & 413.7 & 7.6 & 3203.7 & 15.9 & 28.6 & 1061.5 \\
\hline $\begin{array}{l}\text { Vasylkivska } \\
\text { (Dnipro region) }\end{array}$ & 456.5 & 16.4 & 2994.1 & 12.8 & 19.0 & 789.9 \\
\hline $\begin{array}{l}\text { Vysotska } \\
\text { (Rivne region) }\end{array}$ & 240.5 & 4.5 & 1714.1 & 25.6 & 36.8 & 1035.7 \\
\hline
\end{tabular}

Estimation of natural resources capacity can also be used for: establishment of clusters and other resources-based structures; cooperation of communities and intercommunity relations for common use of resources; securing the sustainable development of territories; search for and revealing the reserves to improve communities' financial capacity.

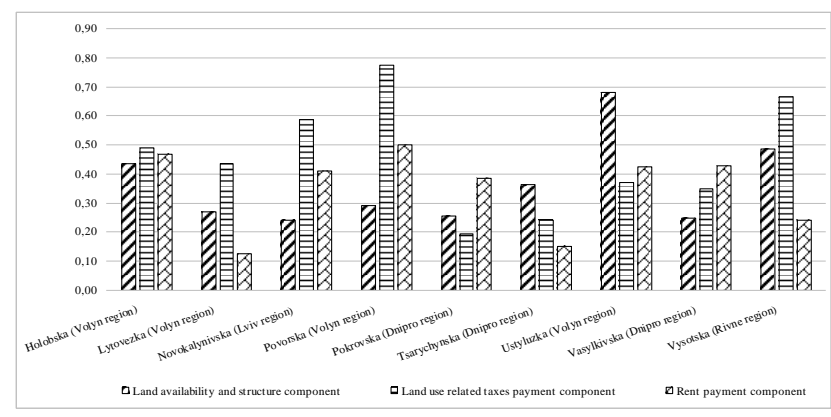

Fig. 1. Natural resources component of endogenous capacity of some consolidated territorial communities in Ukraine, 2018

Estimation of human capacity in the structure of community's endogenous capacity stipulates taking into account the parameters across demographic, intellectuallabour, socio-management, socio-economic, socioinfrastructural and cultural components (Fig. 2).

Calculations of endogenous human capacity for communities make it possible to draw conclusions on priorities of improvement of living environment in order to prevent outflow of population. It can be done based on revealing the noticeable gaps between demographic and other components that form human capacity, namely:

- with intellectual-labour component, which requires promotion of employment and self-employment in a community - for Ustyluzka and Vysotska communities;

- with socio-economic component, which requires increasing of the volumes of disposable income per capita by business stimulation at the territory of a community - for Holobska and Novokalynivska communities;

- with socio-management component, which requires intensification of managerial activity in terms of intermunicipal and cross-border cooperation, attraction of new specialists into the community's apparatus, increasing the level of their remuneration - for Horodnytska, Povorska, Tsarychanska and Ustyluzka communities;

- with socio-infrastructural component, which requires development of the network of medical facilities and improvement of housing- for Povorska and Vysotska communities;

- with cultural component, which requires intensification of cultural activity in a community by establishment of new cultural and sports facilities, art schools and youth centers as well as holding exhibitions - for Lytovezka, Novokalynivska, Povorska and Vysotska communities.

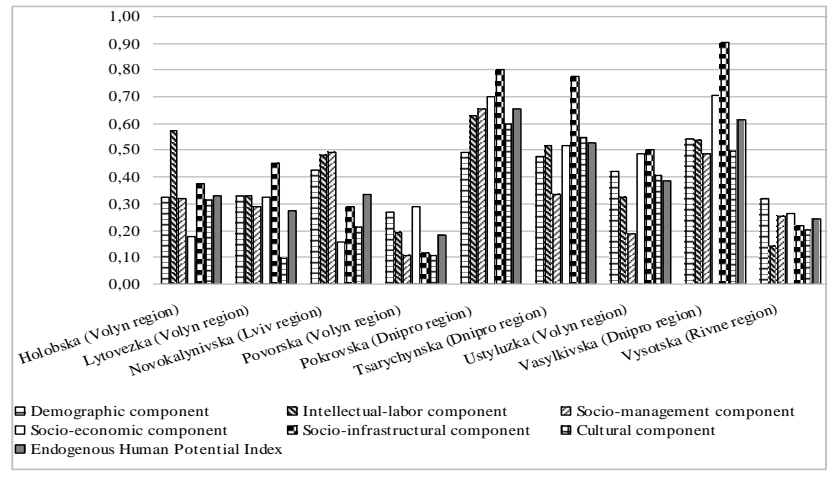

Fig. 2. Human component of endogenous capacity of some consolidated territorial communities in Ukraine, 2018

Vasylkivska community is to some extent exemplary in terms of the use of human capacity, where the rate of human capacity component exceeds substantially the demographic component. It means that currently satisfactory living conditions are created for population.

Fig. 3 shows calculations of financial capacity in terms of expenses for consolidated territorial communities in Ukraine subject to analysis. Application of suggested methodics contributes to revealing the following aspects:

- efficiency and reasonability of expenses on management in a community with comparison of management process organization in various communities;

- peculiarities of social expenses and their efficiency;

- focus of expenses of communities' local budgets on economic activity and main directions of their undertaking.

The use of the methodics of analysis of territorial communities' endogenous capacity stipulates the systemic 
complex research of local budgets of communities as financial foundation of their development. In the first place, the parameters and coefficients are calculated in order to comprehensively analyze the forming and use of local budgets of territorial communities. In the second place, the chosen methodics is directed at revealing the problems of filling local budgets and explaining the ways to increase budget capacity.

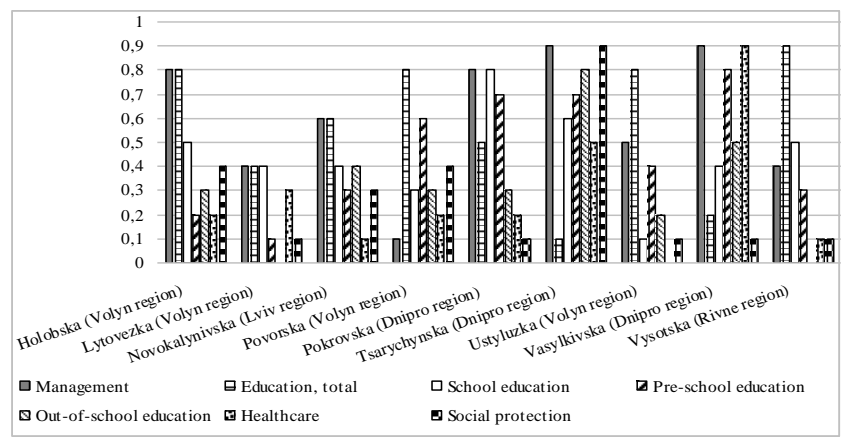

Fig. 3. Fianancial (expenses) component of endogenous capacity of some consolidated territorial communities in Ukraine, 2018

The authors' methodics of estimation of territorial communities' investment capacity is developed based on calculation of sub-indices of provision with financial, labour and productive resources. Taking into account the available parameters, the partial and integral indices of endogenous investment capacity of some territorial communities in Ukraine are calculated (Fig. 4).

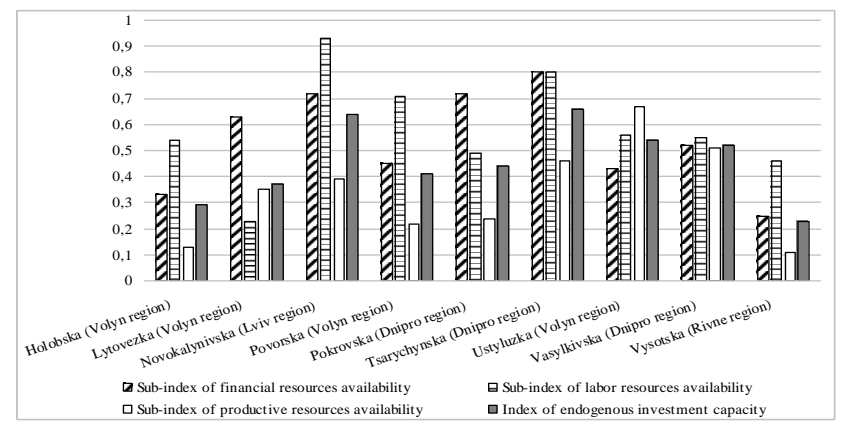

Fig. 4. Investment component of endogenous capacity of some consolidated territorial communities in Ukraine, 2018

Claculations indicate what reserves the communities should mobilize in order to improve investment attractiveness and efficiency of the use of internal opportunities. In particular, the primary need in Holobska, Novokalynivska, Povorska, Pokrovska, Tsarychynska, Ustyluzka and Vysotska communities is to increase productive capacities related to entrepreneurship activity at their territory. Reorientation of communities on the goals of development nature with promotion of employment and entrepreneurship is relevant. Calculations confirm that the component of provision with human resources in the structure of investment capacity analysis hasn't gained sufficient transformation in productive and financial conditions of communities' development.

\section{CONCLUSIONS}

The results of calculations across the defined components of endogenous capacity enable substantiation of priorities of its increase for specific consolidated territorial communities based on fundamental quantitative features of population and available natural resources capacity. Finding the gaps in the component of human capacity defines the priorities of living environment improvement in order to prevent losses caused by migration and aging of population. Financial component gaps define the efficiency of budget funds use. In terms of gaps, investment component also emphasizes the relation between human capacity and the practice of investment resources attraction. Moreover, further testing of the methodics on the examples of other consolidated territorial communities in Ukraine helps substantiating the reasonability of their creation and functioning as well as of further conducting of decentralization reform. In future publications we will develop methodical approaches to the analysis of internally-potential gaps across the defined components of endogenous capacity in order to provide specific suggestions for communities in terms of their development priorities.

\section{REFERENCES}

[1] I. M. Vahovych, and M. S. Zabedyuk, "Nature and structure of a region's endogenous capacity", Economics and State, no. 11, pp. 4143, 2010.

[2] I. I. Shkuratova, "Management of natural resources capacity in economic system of a region", Bulletin of the Academy of Customs Service of Ukraine, Series Public management, no. 1. pp. 92-97, 2011.

[3] P. V. Zhuk, "Natural resources capacity and nature capital in the paradigm of sustainable development of Carpathian region", SocioEconomic Problems of Modern Period of Ukraine, vol. 103, no. 5, pp. 48-57, 2013.

[4] O. M. Suhina, S. L. Shults, V. O. Tkach, N. M. Popadynets, and O.S. Kamushkov, "Methodology of evaluating economic losses resulting from partial loss of the air ecosystem's assimilative capacity", Journal of Geology, Geography and Geoecology, vol. 28, no. 1. pp. 188-198, 2019.

[5] R. V. Yakovenko, "Human capital and human capacity", Scientific Works of Kirovohrad National Technical University, Economic Sciences, vol. 24, pp. 186-193, 2013.

[6] S. A. Skyba, "Role of human capacity in creative economy", Economy and Region, no. 6, pp. 15-20. 2014

[7] O. V. Stefanyshyn, and V. I. Pyts, "Peculiarities of the nature of "human capacity" category in conditions of the development of innovative economy in Ukraine", Halytskyi Economic Bulletin, vol. 28 , no. 3, pp. 161-169, 2010.

[8] S. V. Sember, O. H. Chubar, and K. S. Mashiko, "Theoretical approaches to defining of the nature of financial capacity and financial resources of a territorial community", Regional Economy, no. 3, pp 81-90, 2015.

[9] N. V. Trusova, "Forming of financial capacity of agricultural enterprises: theory, methodology", Dr. Sci. (Econ.), dissertation, National Scientific Centre "Institute of Agrarian Economics", Kyiv, Ukraine, 2016.

[10] T. Y. Nazarova, "Management of financial capacity of industrial enterprises based on synergy approach", Bulletin of the Odessa National University, Series: Economy, vol. 8, pp. 67-72, 2016.

[11] A. Ya. Kuznetsova, H. V. Voznyak, and I. V. Zherebylo, "Social and economic effects of inter-budgetary relations' decentralization in Ukraine: assessment and challenges", Financial and credit activity: problems of theory and practice, vol. 4, no. 27, pp. 446-456, 2018.

[12] M. M. Pitylych, K. S. Mashiko, K. M. Kudak, and M. M. Paush, "Capacity of a territorial community: peculiarities of forming and development”, Young Scientist, no. 4, pp.155-160, 2016.

[13] M. S. Kukosh, “Concept of forming of a region's investment capacity", Scientific Bulletin of Uzhorod National University, Series: International economic relations and global economy, vol. 19, no. 2, pp. $66-70,2018$ 